\title{
Helping to Undo the Past: Teaching Critical Reasoning in SouthAfrica
}

\author{
STEPHEN DE Wisze, The University of Manchester
}

\begin{abstract}
In this paper I discuss the opportunities and difficulties of teaching critical reasoning in a rapidly transforming society such as South Africa. I argue that the real benefits for students of such courses outweigh the pessimism of John McPeck and Richard Paul that they do little, if any, good. This paper is based on my experience of having taught critical reasoning at school and university level in South Africa during the early 90 's.
\end{abstract}

Résumé: Je décris dans cet article les chances et les difficultes de l'enseignement de la pensée critique dans une société en rapide transformation comme l'Afrique du Sud. Je soutiens que les bénéfices qu'un tel cours procure aux étudiant(e)s dépassent les attentes pessimistes de John McPeck et de Richard Paul, selon lesquels ces cours apportent peu, à supposer même qu'ils apportent quelque chose. Cet article se fonde sur mon expérience dans l'enseignement de ces cours aux niveaux secondaire et universitaire en Afrique du Sud au début des années 90 .

\section{Introduction}

For several years now I have been teaching critical reasoning courses which John McPeck' argues will not provide students and scholars with the requisite critical thinking skills. Furthermore, largely because of time and financial constraints, the courses have been of the kind that Richard Paul ${ }^{2}$ argues are atomistic and largely unhelpful in developing critical thinkers. I think that both McPeck and Paul are wrong on two counts. First, they underestimate the extent of the skills learnt from such courses and the extent to which it helps students towards the goal of becoming critical thinkers. Second, they downplay the importance of such skills for people who are living in a country like South Africa which is emerging from the apartheid era and undergoing major social and political changes.

The purpose of this paper is twofold. First, I present an account of the particular, perhaps unique, conditions in which critical reasoning courses are taught in South Africa. Some of these conditions provide excellent opportunities to achieve what I take to be the aims of a critical reasoning course. I discuss these conditions which I have gleaned from my experiences teaching critical reasoning courses to school pupils and university students in the Eastern Cape noting that there are also particular difficulties which arise when teaching to students who come from severely disadvantaged educational backgrounds. Second, I argue, counter to the views of John McPeck and Richard Paul, that some general reasoning skills and critical thinking dispositions are indeed teachable using what Robert Sternberg ${ }^{3}$ refers to as a "mixed method" of teaching critical thinking. I present some empirical evidence from pupil assignments and student course evaluations to support my claim. I begin the paper by providing some necessary background concerning the South African secondary education system, the 
courses I have taught and what I understand is required of a teacher of critical reasoning who wants to encourage the development of critical thinkers. Overall I do not think that I say anything new, or arrive at any startling revelations. However I do provide some empirical evidence to support the theoretical arguments against McPeck's and Paul's positions. Furthermore I hope to capture the particular ambience in which critical reasoning courses are taught in South Africa and the real benefit of such courses in a country which is moving through a period of major social and political change.

\section{Background}

\section{Critical Thinkers And General Reasoning Courses}

Part of my brief as a lecturer at Rhodes University is to teach a course on critical reasoning to 1st year philosophy students. I have taught this component of the course for several years now. I often begin this module, feeling brave and a little foolhardy, by telling the students that this module has three main aims: 1) to show them how to find the truth; 2) to reshape and mould their minds in (at last) the proper and correct way and 3 ) to set them free.

These comments are meant to incite. I want vigorous protest, perhaps outrage about my arrogance and misplaced certainty, or perhaps from the more polite and retiring, expressions indicating a puzzlement if not cynicism about my intended aims and motives. The reaction is usually predictable for South African students (and perhaps for students elsewhere too): a few snigger (one or two may laugh out loud); some sit impassively with no sign that they have even heard what I had just said; one or two continue to stare longingly out the window, but the vast majority diligently write my comments down presumably so that they can commit them to memory later that day (or for the less diligent, before the first class test!)

This annual event offers an insight into the educational backgrounds of most South African students. It gives a clue of where a critical reasoning course needs to begin and whether one can hope to achieve the aim of producing critical thinkers. I find Ralph Johnson' $s^{4}$ account of what it is to be a critical thinker the most useful model to follow. He contrasts a critical thinker with those of a dogmatic (uncritical) thinker and a creative thinker. A dogmatic thinker may be sophisticated or vulgar where the latter operates by mouthing slogans while the former is solely interested in destroying an opponent's position. Critical thinking differs from dogmatic thinking in that it rejects slogans and tries to enter empathetically into the other person's world view (or as Richard Paul' puts it, "Form of Life") in order to better understand one's own position and where necessary improve upon it. A creative thinker differs from a critical thinker in that she brings a product into existence, while a critical thinker assesses an intellectual product (and this may or may not require argumentation theory). So to become a critical thinker requires that, first, one have an extensive background information/knowledge concerning the debates and facts surrounding the particular issue. Second, a person needs to have the correct traits, attitudes and dispositions to begin the process of critical thinking. Amongst these traits and dispositions is the desire to seek the truth, a sense of fair play, tolerance for ambiguity and uncertainty, 
the capacity to accept criticism, the willingness to question one's own motives and basic assumptions, a sense of balance and a faith in the power and convicting force of rational discourse so that one is appropriately moved by reasons. Third, to be a critical thinker requires the skill to identify, analyze and evaluate (and perhaps to construct) arguments. It requires the ability to weigh evidence, construct arguments and counterarguments and root out fallacious or bad arguments.

It would be naive in the extreme to believe that a short reasoning course lasting a few months could produce critical thinkers. To become a critical thinker requires a life-time of effort. But it seems to me that in a critical reasoning course, some important foundational reasoning skills can be taught and the correct attitudes and dispositions encouraged. It is also possible to provide an in-depth study of one or two topics so that students can develop the essential background knowledge necessary to make informed reasoned judgments about certain issues and from this experience, extrapolate to others they will have. In a short reasoning course with school children at Kingswood College (a South African secondary school), the entire course focused on the question of whether one ought to be a vegetarian as a vehicle for discussing critical reasoning skills. At the end of the course, pupils began to understand (probably for the first time) the immense complexity of the issues involved, and were able to discuss the topic at a fairly sophisticated level indicating that they had achieved more than a superficial insight into the question.

To avoid any later confusion I must make it clear how I shall use the terms critical thinking, and critical reasoning.

Critical thinking refers to a rather broad notion. It is the skills a person has who is capable of "reasonable reflective thinking that is focused on deciding what to believe and what to do" because this person has the disposition to so behave and think rationally. ${ }^{6}$ Such a definition includes within it the skills of critical reasoning and much more. The notion of a critical thinker denotes a moral and intellectual virtue of which a component would be the skill of critical reasoning - the identification, analysis and evaluation of arguments. Also included in the notion of a critical thinker is a person who has a level of self-awareness, autonomy, self-sufficiency, the ability to be imaginative, use insight and, very importantly, the disposition to engage in the activity of being rational and reasonable. (Being a critical thinker is not identical with being a logical thinker which is a component of it.)

Critical reasoning refers to the skills and techniques that are required to enable a clear and accurate analysis of arguments, deductive and inductive, to be able to break down problems into their component parts, spot irrelevances within the argument structure and content, identify relevant premises and assumptions while examining and testing inferential connections between statements. Critical reasoning skills are essential for judging the soundness or strength of arguments and form the basis of any academic inquiry.

The courses which I taught were largely critical reasoning courses in that they attempted to teach some general reasoning skills and techniques. However I also undertook to encourage the dispositions and attitudes necessary for becoming a critical thinker. In a course to school pupils, I also attempted to give pupils a deeper under- 


\section{Stephen de Wijze}

standing of one topic so that they would have an insight into the complexity of issues and the background knowledge required to successfully evaluate arguments.

Certain educational and socio-political conditions which exist at the moment in South Africa have an important effect on the possibility of successfully teaching a critical reasoning course. But before discussing them I must offer some background information pertinent to the South African school and university environment.

\section{Rhodes University And Kingswood College}

Much of the data I use in this paper arise out of critical reasoning courses I have taught to university students (Rhodes University) and high school pupils (Kingswood College). I teach philosophy at Rhodes University, a small university (4000 students) in Grahamstown in the Eastern Cape in South Africa. ${ }^{7}$ The students come from all parts of the country and a few from as far afield as Zimbabwe, Zaire, Zambia, Ghana, Malawi, the UK and the USA. The reasoning course is taught as a component of the first year philosophy course called Introduction to Philosophy (ITP) ${ }^{8}$ It normally attracts approximately 65 students, ${ }^{9}$ with slightly more women than men. The majority of students $(70 \%)$ are Whites with the rest being Coloured, Indians and Blacks. ${ }^{10}$ All students who register for ITP must take the reasoning course as part of this first year credit. This course is taught over 5 months simultaneously with a course on Philosophical Problems. The critical reasoning course is always taught (when possible) in the first semester, as it is assumed to lay the basis, that is, provide the basic reasoning skills, upon which the other courses can build.

Kingswood College" is a private coeducational secondary school situated in Grahamstown. I co-taught a critical reasoning course to the most gifted Standard 9 students ( 16 year olds) over a 3 month period. The class consisted of 17 pupils. There were 8 boys and 9 girls. Most of the students come from privileged backgrounds. An informal inquiry into their home backgrounds indicated that their parents were lecturers, teachers, farmers and business men and women. 13 pupils speak English as their home language while the remaining 4 spoke either Xhosa, Sotho or Afrikaans as their first language. The language competence in the class varied considerably. In the last class mark order, which took into account comprehension tests, essay writing, letter writing, poetry tests and poetry presentations, their English marks ranged from $35 \%$ to $80 \%$ None of the pupils had been previously exposed to a critical reasoning course. Given the short duration of the module, the background of the pupils and the nature of the skills this reasoning module attempted to impart only some of the critical reasoning skills which I believe ought to be pursued in a lengthy critical reasoning course and as a life long activity thereafter.

\section{Christian National Education (Cne) - A Brief Synopsis ${ }^{22}$}

Due to the apartheid policy of the last 4 decades, education has been segregated with huge inequalities between White, Black, Coloured and Indian schools. ${ }^{13}$ All students who were schooled in South Africa over the last 40 years have been subjected, to a greater or lesser degree, to a policy of Christian National Education (CNE). Even if students attended private schools, the teachers employed are likely to have been schooled 
and trained in an environment where the influence of CNE was a dominant force. Consequently the impact of CNE has been enormous whether as an ideology which influenced the world views of Whites or as an ideology which was bitterly fought against (as was the case in Black education). Its legacy has consequences for educators in general and those teaching critical reasoning courses in particular.

What is the work of an educator according to CNE? A full discussion is well beyond the scope of this paper but its general tenor must be given.

Education is a particular occurrence in accordance with accepted values and norms of the educator and eventually also of the group to which he belongs. He is engaged in accompanying the child on the way to self-realisation, but this realisation must be in accordance with the demands of the community and in compliance with the philosophy of life of the group to which he belongs. In this way the South African child has to be educated according to Christian National principles. ${ }^{14}$

The accepted values and the demands of the community in the South African case were those of the White, mainly Afrikaans speaking, community as understood by the Nationalist government. Whites and Blacks were to be educated differently according to their specific cultures and allocated social positions in South African society. Educational control was to remain with the White authorities who would ensure that no false foreign ideologies interfered in the education process with sham goals and ideals. It is widely documented and hardly controversial that CNE offered an apology for a racist, unequal education system whose aim was to maintain and defend the ideology of apartheid which entrenched White privilege and power in South Africa.

Part of the legacy of CNE, apart from the conflict it generated and the huge waste of human and material resources, is that its long reign as the official educational policy, it has produced students of all races who exhibit (to a lesser or greater degree) many of the following behaviours (1-4) and attitudes (5-11):

1) A considerable lack of any critical faculty regarding information they are offered in lectures/seminars or which they glean from texts.

2) Basic inadequacy in reading and writing skills. This is exacerbated in the case of Black students who may be using English as their 2nd or 3rd language.

3) Marked lack of investigative and research skills.

4) Marked lack of general knowledge on a vast range of issues.

5) A belief that every problem always has a clear, simple and right answer which can be given by the appropriate authority.

6) Scholarship and the mastery of a topic is understood as rote learning of the relevant facts and figures given by the appropriate authority.

7) A lack of empathy with different world views or value systems resulting in intolerance and fear of different values, lifestyles, opinions.

8) Fear of questioning their own fundamental assumptions and beliefs so that there is a naivety and innocence towards claims that originate from within their own world views.

9) A marked dislike and low tolerance for complexity. There is a strong psychological need to simplify issues and problems. 
10) Support for claims, theories and especially controversial political, ethical or social arguments are based on an attitude towards the originator of the claims. Loyalty rather than reasoned argument constitutes the criterion for support.

11) Marked lack of faith in reason and rationality to be able to persuade others of one's claims. Controversial issues are understood as issues where persons hold irreconcilable and mutually exclusive opinions.

The list above ${ }^{15}$ points to an educational failure of a marked degree over the last few decades. Our educational system has effectively prevented or severely retarded pupils/students from all sectors of South Africa from developing as critical thinkers; that is, from developing the appropriate critical thinking skills and the disposition to use them. In short they lack what Postman and Weingartner call "a Shockproof Crap-Detector".'s These attitudes and behaviours become evident in the classroom and provide part of the background which a critical reasoning course in South Africa needs to take into account.

\section{The Call For Critical Thinking In South Africa}

It has become the received wisdom amongst educators, employers, politicians and professionals over the last few years that South A frica urgently needs to begin producing critical thinkers. The call, it seems, emanates from two main growing concerns. First, there is a dearth of skilled professional and white-collar workers needed to ensure the growth of a modern economy. This lack of skilled persons threatens to seriously retard economic growth which in turn will bring about an increase in social and political ills. In a recent symposium on the employability of BA graduates, employers, educators and professionals made a plea for developing graduates who exhibit insight and competence, independent critical thought, creativity in the application of knowledge, innovative thinking, openness to alternative points of view, rationality and objectivity with corresponding verbal and written communicative skills, and the improvement of analytic, logical and abstract thinking skills. This new attitude is summed up by the director of Industrial Relations and Public Affairs of the Anglo American Corporation (Mr Bobby Godsell) who claims that: "At the heart of knowledge are the skills and disciplines of critical thought and reasoning."

The second concern arises from the political needs of a country undergoing a very difficult transition to a non-racial democracy. As was noted in the previous section, the education system has ill prepared students for a life of critical thinking. For a new South A frica to succeed the country needs a new tolerance amongst Whites and Blacks, an innovative approach to solving conflicts; one which will find new solutions to the old problems of resource distribution, education, health etc. The call for critical reasoning courses at university and school levels reflects concern with the ability of persons graduating from our schools and universities to meet the economic and political challenges of the next decade.

Perhaps the call for critical thinkers is also due to a realisation amongst large sectors of the population themselves that they need new analytical tools to understand the rapidly changing society around them. The recent exposé of long-time govern- 
ment involvement in violence and corruption, reports of brutal behaviour in ANC training camps and the proliferation of accusations and counter-accusations amongst politicians leave the general populace bewildered if not cynical and disillusioned with the leaders of the country. A need arises for a neutral and objective way of assessing dayto-day claims that are made in the press and elsewhere. Honing one's critical reasoning skills is seen as one possible way to rise above the muddle and confusion. In 1992, I asked all ITP students to fill in a questionnaire prior to taking the course and one of the questions asked what they hoped to learn in a critical reasoning course. The vast majority, well over $90 \%$, said they hoped to learn how to think or reason better. But, significantly, a very large percentage also hoped that such a course would broaden their horizons, enable them to have a better understanding of the world around them and help them to understand other persons' and groups' worldviews. (See appendix 1) In short, there is a strong belief that philosophy in general, and critical reasoning in particular, will make them better thinkers and, in the end, better people.

\section{Justifying Critical Thinking}

Despite the call from a wide range of persons and organisations for critical reasoning courses, such an educational aim is not universally accepted. One finds opponents of critical thinking across a wide spectrum in South Africa. There are those who reject the goal of producing critical thinkers on religious grounds. Opposition also comes from certain political philosophies. A crude marxism rejects the notion of a critical thinker as grounded in a liberal, bourgeois and ahistorical account of individuals and society. Far right-wing and left-wing groups pay no more than lip service to the claim that the problems of South Africa must be solved by negotiation and compromise. For them, loyalty to a leader or stated ideal is all important. Within the philosophical world there are those who reject the very possibility of producing critical thinkers using critical reasoning courses because they argue that such a project is theoretically impossible. Relativists claim that there are no universal standards of evaluation possible across cultural or epistemological views. Jacques Derrida, for instance, would assert that to teach critical reasoning skills is to fall prey to a logocentric view of the world. Consequently there is a need to offer a justification for such a project. ${ }^{18}$

Such a justification, I believe, rests on the principle of respect for persons. To acknowledge critical thinking as a virtue presupposes that one endorses the virtues of self-sufficiency and autonomy as values that are good-in-themselves. Education is seen as a process which will equip or empower pupils/students to competently take on jobs, positions in their society, roles and interests that they perceive to be in their best interest and which will allow them to pursue their own conception of the good life. Education that attempts to indoctrinate persons into a particular political, social, or religious worldview stands in stark contrast to the main guiding idea of developing critical thinkers. I contend that what is wanted and needed in a new South Africa is a democratic open society. Such a society presupposes autonomous, self-reliant individuals and so the task of developing critical thinkers is of paramount importance. In short, there is a pragmatic and a moral justification for fostering critical thinkers. Critical thinkers are in a much better position to defend themselves against a host of unethical ideologues, 


\section{Stephen de Wijze}

advertisers and any others who wish to manipulate them. And the moral justification rests on the fact that critical thinking attempts to empower persons to become autonomous and independent thinkers; that is, to treat persons with respect as ends in themselves. ${ }^{19}$

\section{Teaching Critical Reasoning Courses In South Africa - The Particular Conditions}

There are conditions particular, perhaps even unique, to South Africa which provides a milieu in which attempting to nurture critical thinkers is important and rewarding but which also makes teaching critical reasoning skills frustrating, if not sometimes well nigh impossible. I am confident that these conditions do not exist in countries like the UK and USA (or at least not to the same degree), but they may be present in other countries undergoing similar changes to those occurring in South A frica. South Africa has a unique mix of conditions, two of which have a marked effect on the teaching of critical reasoning courses in particular and the attempt to nurture critical thinkers in general. First, South Africa is undergoing vast and far-reaching changes to its political and social fabric which provide a receptive environment for the teaching of critical reasoning courses. Second, with these changes, for the first time there is a mixing of students and pupils from a wide range of cultural, social and educational backgrounds in the same classes. I shall discuss the pros and cons of each of these conditions in turn.

\section{Rapid Social And Political Changes}

Critical reasoning courses are being taught in a time of enormous social, economic, political and cultural upheaval in South Africa. The old order, with its certainty and authority, is rapidly giving way to the new, and with this turbulent change comes uncertainty and instability and the consciousness amongst students and pupils that the understanding of political, economic and cultural issues is urgent and of immediate importance to their lives. Student and pupil motivation to undertake critical reasoning courses is high, at least initially so. This is borne out by general widespread student enthusiasm for such courses providing one of the possible reasons for the large increase in student numbers over the last few years taking ITP (and majoring in philosophy in general) at Rhodes ${ }^{20}$ with similar trends in most universities across the country.

School pupils also expressed an interest in pursuing issues that had a direct bearing on political and social issues presently being hotly debated by the country's politicians. In a course evaluation given to pupils at Kingswood College after the critical reasoning course I asked them:

"What other topics (besides vegetarianism) would you liked to have focused on?"

The replies concentrated on the following issues: racial discrimination, current affairs, human rights and politics. In a follow-up questionnaire eight months later I again asked:

"Would you want a critical reasoning course focusing on contemporary po- 
litical issues that concern South Africans today?"

There was an unanimous agreement that such a course would be welcomed and very useful to pupils.

This interest in attending critical reasoning courses focusing on contemporary South African political and social problems is not hard to explain. There is a need for, and a keen interest in, finding answers, (or at least a reliable, impartial and reasonable method for finding answers), to vexing and complex problems that will have a direct and lasting impact on their lives. In the USA and UK, university work is often seen as purely "academic." And while stability and order prevail it is an academic exercise to ask what would happen if a communist party took power (or had real and significant influence over the party in power) in 5 month's time, or whether a woman's right to have an abortion should be protected under a new constitution. In South Africa these are immediate concerns. ${ }^{21}$

In addition, with the change in political dispensation, there is a need to find a way to bridge enmities which have become more and more marked and open as the struggle for power in South Africa intensifies. It is clear that amongst reasonable people there is a desire to foster a new empathy for the other's point of view so that there can be a meaningful and lasting solution to the conflict in the country. Until fairly recently, politicians, both Black and White, have remained in power, or sought power, by highlighting and emphasising differences between groups in the country. The views and goals of the other were characterised as threats to one's own cherished values: as uncivilized or demonic or immoral. With the new political order there is a realisation that there is a need for a modus vivendi. This requires that, at the very least, different groups must learn to discuss and solve their problems using rational persuasion, bargaining and where necessary compromise. If this method fails, if South Africans are unable to find solutions based on the power and convicting force of reason, then the alternative is a prolonged and bloody civil war. ${ }^{22}$

It is also worth noting that as the current regime's hold on power diminishes and other views are presented in the media, there is a new awareness that the issues and problems being discussed and negotiated are complex. Previously, the government controlled media were able to offer, with impunity, simple and often entirely false accounts of their opponents' positions and goals.

With this complexity comes the realisation that to be able to competently judge competing views, requires some training in and understanding of reasoning skills. This is reflected in the comments made by pupils and students when asked why they chose to read philosophy and what they hoped to gain from taking a critical reasoning course. (see appendix 1)

This rapid change in political and social conditions, the need to bridge enmities and the realisation of the complexity of issues provide fertile ground for sowing critical reasoning courses. The students require minimal motivation, and there is a wealth of everyday real examples to draw upon when illustrating a particular reasoning skill or technique. (South African politicians are skilled in non-sequiturs, the ad hominem and genetic fallacies!)

However, there are also problems which arise from teaching in this milieu. First, 
students tend to have unrealistically high expectations of a critical reasoning course. This is compounded by the short period of time that is spent on such courses. (My ITP course runs for 5 months and consists of 6 tutorials and 20 lectures and the Kingswood College course consisted of 10 lecture/tutorial sessions..$^{23}$ ) Students often are disappointed after completing a critical reasoning course as they have not become the critical thinkers they thought they would become. The miracle they were hoping for did not come to pass. The learning of a skill is a slow and frustrating process and can take many years. Second, the complexity of issues, short courses and the difficulty in developing a new skill tends to result in the phenomena I have called Block-out and Hyper-criticism. These phenomena probably also occur in countries like the UK and USA, but I suspect that they are more pronounced in South Africa.

With Block-out the following occurs: Students and pupils begin the course with enthusiasm and soon begin to jettison their old preferred method (whatever it used to be - rule of thumb, intuition etc.) as inadequate for the analysis of argument. Soon, however, they feel that they have not picked up the new requisite skills to replace their old methods of judging between different arguments or world views. The result is a paralysis and disillusionment with their own abilities and the aims of the critical reasoning course. I found this phenomenon occurring both at school and university level. Even course participants with much experience in critical thinking and who prior to the course were fairly confident and capable of reading and criticising texts - graduate tutors for example - become convinced after a few sessions that they are incapable of doing any critical thinking at all. A sudden realisation of how difficult critical thinking can be, combined with the problems of learning new skills, tends to sap confidence. If a student drops out at this stage (and many do), I believe that she is left worse off than before she started the course. It is as if a formal course on critical reasoning renders all previous experience of critically reading texts and thinking critically about issues, null and void.

Hyper-criticism occurs when students err in the other direction. Here students acquire a taste for criticism and soon become so critical that they find faults in perfectly good arguments. They forget that a critical thinker seeks to understand their opponent's position, learning from it and if possible improving their own understanding. They forget to apply what Alec Fisher refers to as the Principle of Charity ensuring that the purpose of critical analysis is to seek the truth rather than simply destroy the opponent's argument. ${ }^{24}$

These problems can be mitigated to some extent by avoiding jargon, providing fairly easy assignments at the start of the course combined with continual reassurance that as the course progresses so their ability in critical reasoning will improve at an exponential rate! But most importantly, it is necessary to impress upon students that the critical reasoning course is only a beginning of a life-long process.

Other factors also make the teaching of critical reasoning courses difficult. The immediacy of examples used, the intolerance and irrational behaviour, the strong opinions of other students, and perhaps having been a victim of the policies of a view postulated by another student understandably tends to frighten and alienate. This is the negative side to local topics being interesting and relevant. Students who become distressed by the topic and the views expressed by others revert to emotional responses 
and retreat into slogans. Empathy and tolerance of other's points of view and claims collapses and are very hard, if not impossible, to resuscitate.

\section{Diverse Social, Cultural And Educational Backgrounds}

The second particular condition that aids the teaching of critical reasoning courses is the political, social and cultural diversity of the students attending such courses. Students come from vastly different educational, socio-political and cultural backgrounds. This provides excellent opportunities for a diversity of opinions, views and beliefs in the class. There is no need to play the devil's advocate to offer a plausible counterargument to a stated point of view held by an individual or group of students. It is likely that there will be a natural disagreement on social and political issues which can be exploited to illustrate reasoning skills. Capitalists and communists sit in the same class. Those who support the Nationalist Party sit side by side with those who support the African National Congress (ANC), The South African Communist Party (SACP) and the Pan Africanist Congress (PAC). When discussing the topic of analogies I use an example from Trudy Govier's book, ${ }^{25}$ an analogy employed by Glenn Babb (a South African government representative) and later by Ronald Reagan to show how sanctions against South Africa could be detrimental to the very people they were trying to help. I present this example after explaining that the strength of an argument from analogy depends on the relevance of the similarities mentioned in the premises to the similarity stated in the conclusion. I then ask whether the following is a strong argument from analogy.

There is no point in western countries applying economic sanctions to South Africa in an attempt to help black people there. Sure, sanctions will hurt the economy, but it will hurt everybody. You can see this when you think of killing a zebra. If you shoot him in a white stripe he will die and if you shoot him in a black stripe he will still die. The whole animal goes down. And so it will be with the South African economy. The whole country will suffer from sanctions - not just the white part of it.

I rarely have to say more for the rest of the class except to try and contain the heated discussion that ensues and remind students that the object of the exercise is not to crush those who disagree with them but rather to establish whether Babb used a good argument to support his conclusion.

Another obvious advantage is student exposure to many different strongly held views. This enables a broadening of perspectives and an opportunity to interact under safe conditions with persons who hold very different views and opinions on life. But again this diversity can also create problems. Different standards of secondary schooling, the fact that for many in the class English is a second or even third language, and the difficulty some students experience with the language level in the American and British textbooks tend to slow the pace of progress in the class. Difficulties arise both with the large differences in the standard of secondary schooling between Whites and Blacks and also from certain similarities in training. The differences tend to manifest in the often superior verbal and writing skills of students who attended private schools or the historically White schools. Students from historically Black, Coloured or Indian schools tend to have greater difficulty in expressing themselves, often find the texts difficult to understand and are perceived to be unable to acquire the skills being taught. 


\section{Stephen de Wijze}

Formal logic, for example, tends to present a bigger problem for Black students who have had very little exposure to mathematics with its requisite skill of rigorously manipulating symbols. This difference tends to make pitching the appropriate level of the course and the pace at which it should be taught a difficult process. However this is not an insurmountable problem since these discrepancies can be compensated for by extra tutorials and close supervision. This difference also tends to become less marked as the course progresses, certainly for those students who are motivated and work hard.

A far more trenchant problem is the basic education most of the students (and pupils) received in their secondary schools. (See above for the list on the effect of CNE.) It takes quite a while for students to stop believing that to understand a topic requires that they learn off by heart the "relevant" facts given by the lecturer. They become alarmed and somewhat insecure when I tell them that rote learning in a critical reasoning course is neither wanted nor desirable. Furthermore, students tend to hold strong ideological views coupled with a lack of basic knowledge on a whole range of issues often needed to enable a reasoned judgment between two claims on a particular issue. For example, a large number of students I have taught have never heard of Darwin's theory of evolution, a topic which has not been taught in most secondary schools (and is a fairly recent addition to the curriculum where it is taught) due to the controlling influence of Christian National Education. Consequently an article by Stephen Jay Gould on "Evolution as Fact and Theory"26 is considered to be a very difficult article (and for some students quite alarming) largely due to the fact that this may be their first exposure to the theory of evolution.

Another immensely difficult task is to foster the disposition to be "appropriately moved by reasons", ${ }^{27}$ If good reasons are found to abandon a claim, then continued support from a sense of loyalty (all other things being equal) is misguided at best. Students beliefs and judgments tend to rely too heavily on group or community or party identification. "Viva Einstein's Theory of Relativity!", a statement made by a student to one of my colleagues, is an amusing reductio of this disposition. Many students find it difficult to understand that arguments need to be supported by good and relevant reasons if they are to be supported at all.

To sum up: Teaching critical reasoning helps to undo the prejudice, ignorance and other destructive influences of apartheid secondary school education in South Africa, albeit in a small way. I contend that it is possible to teach general reasoning skills and that students (both graduate and undergraduate) and school pupils benefit from such courses. The question of whether such general reasoning skills can be taught is controversial and I briefly discuss two dissenting voices in the next section.

\section{Teaching General Thinking Skills}

Let us return to the claims made by McPeck and Paul concerning the teaching of critical reasoning. I briefly outline and then dismiss as misguided, or at least unduly pessimistic, their claims about the possibility of teaching a general critical reasoning course. Furthermore, for a country like South A frica, critical reasoning courses offer a generation of students their first introduction to a rational and reasonable method of examin- 
ing controversial issues in a critical manner. The benefits of such a course tend to be enormous. Such courses empower students so that they experience a sense of liberation from a repressive and very bias school education.

McPeck argues that the attempt to teach general critical reasoning skills is "importantly misguided." 28 This is not to say that McPeck rejects the ideal of developing critical thinkers. As he says, "we all agree that ignorance, indoctrination and unreflective conformity are the enemy." ${ }^{29} \mathrm{He}$ believes that the method of teaching a general critical reasoning course cannot help towards creating critical thinkers as thinking skills are necessarily content bound. Thinking skills are not "something different from, or over and above, disciplinary thinking (as implied by the thinking skills movement) but are in fact part and parcel of disciplinary thinking." ${ }^{30}$ In short, reasoning skills are subjectspecific and learning critical thinking skills requires the immersion approach. ${ }^{31} \mathrm{McPeck}$ offers the following argument to support his view.

$P 1$ Thinking must always be about some $X$.

$\mathrm{P} 2$ Every $\mathrm{X}$ must be discipline specific.

C Therefore there cannot be general thinking, that is, thinking about some

non-discipline specific $X$, so there cannot be general thinking skills. ${ }^{32}$

It seems to me that there needs to be two separate responses to McPeck's argument. The first is to refute his position on a theoretical level. Second, his position can be shown to be unconvincing when faced with practical evidence of the benefits, both in an acquisition of general reasoning skills and the adoption of a critical attitude towards claims made in texts and elsewhere.

Theoretically, McPeck's argument is shaky due to his reliance on premise 2. As Vermaak points out, ${ }^{33}$ this premise seems to be false (or at least not obviously true) since there appears to be bits of reasoning which are clearly cross-disciplinary. Modus Tollens and the formal fallacy of Denying the Antecedent apply equally to reasoning in Sociology and Physics. Questions about the relevance of claims used to support conclusions and the focus on possible ambiguities in language form an important part of general reasoning skills whether one is thinking about, say, Chemistry or Psychology. What is more, McPeck uses the concept of a subject as if it were an unproblematic natural boundary which separates one kind of thinking from another. But surely this is not the case. Do questions about the nature of the mind fall under the subjects of Physics, Psychology, Theology, Computer Science? And once one begins to define thinking skills as solely subject specific then to what degree must differences within say Physics, Biology or Sociology, be recognised? Do the thinking skills required in a study of Organic Chemistry necessarily differ from those in Inorganic Chemistry?

McPeck's position also seems to contradict my practical experience of student and pupil development during and after attending a critical reasoning course. ${ }^{34}$ Assessing whether students have learnt general reasoning skills which they transfer to other aspects of their lives is very difficult indeed. I know of no comprehensive longitudinal studies which have been done to show that critical reasoning skills do transfer eventually to other areas of a person's life. I have also seen no study to show that they do not. But I believe I have good anecdotal evidence derived from the many courses I have taught, from reported experiences of colleagues teaching similar courses, from 


\section{Stephen de Wijze}

positive comments in course evaluations and in discussions with students and pupils to substantiate this claim. Many students strongly assert that work done in critical reasoning courses helped them in their understanding and analysis work in other subjects. Just being introduced to the language of argumentation provided them with the tools and awareness to begin the process of becoming critical thinkers ${ }^{35}$ It seems to me that even after relatively short courses (such as the one I co-taught at Kingswood College) pupils were able to begin identifying, analyzing and evaluating arguments. The more able pupils were even beginning to develop their own arguments to support their claims. A clear development in language skills and the understanding of the process of critical reasoning is evident from the work they submitted. (I have included examples of this work in appendix 2.)

What is more, students and pupils definitely begin to adopt a set of attitudes which begins the process for them of becoming critical thinkers. Comments in course evaluations, from pupils in school to post-graduate students point out that since they have done a critical reasoning course they are more aware of attempts by the media, politicians, advertisers and friends and relatives to use poor arguments to defend controversial claims. As mentioned above, in the South African context, a critical reasoning course also begins to provide the insight and skills in how to find information about a variety of topics, to be open minded to different viewpoints and to realise the complexity of many issues. These insights and skills begin to fill in the gaps left by a very poor schooling experience.

This leads to my criticism of Richard Paul's position. Paul argues that we must teach critical thinking in the "strong sense" if we are to develop critical thinkers. The mixed method approaches the study of arguments atomistically (critical reasoning in the "weak sense") which results in a detrimental simplification of complex arguments. This process is unsatisfactory and is not an optimal way to effectively nurture the development of critical thinkers. To teach critical reasoning in the "strong sense" requires students to identify the world views or "forms of life" they themselves hold and those in which their opponent's arguments are embedded. It is by adopting a global approach, by emphasising argument networks rather than "atomic arguments," by concentrating on a more dialectical and dialogical approach instead of evaluating atomic arguments that one develops critical thinkers. ${ }^{36}$

Whereas Paul's ideas undoubtedly hold some truth and in an ideal world would be implemented, in the South African context they are wholly impractical. First, such courses would require an enormous outlay of time and educational resources which are under ever increasing pressure. To teach critical reasoning in the "strong sense" requires, as Paul himself points out, courses that last over years rather than months. ${ }^{37}$ It is difficult enough to find the time and the finances to give short critical reasoning courses despite the general enthusiasm for these courses. Paul's conclusions are too pessimistic. Short courses do have a significant impact and in South Africa they provide many students with their first exposure to any kind of critical analysis of claims made by the media, politicians etc. These short courses try to both impart some general reasoning skills and foster the necessary attitudes and dispositions which are necessary conditions for becoming critical thinkers. Given the educational background and the changes occurring in South A frica these courses are a valuable and formative 
experience for most of the students.

\section{Conclusion}

Critical reasoning courses need to be taught in South Africa. They should aim to empower students and pupils by beginning the process whereby they can more easily develop as critical thinkers. Such courses can be based on the "mixed method" approach which tries to impart general reasoning skills and the correct attitudes and dispositions for critical analysis. The changing political and social milieu makes teaching such courses morally and practically imperative as South Africa needs to begin producing graduates who are in a position to meet the challenges of a new developing country trying to shake off the problems of a past unjust regime. At present the teaching of critical reasoning courses is largely confined to philosophy departments which reach far too few students. Although critical reasoning courses cannot be a panacea for all South Africa's ills, if widely taught and supported by educators, the state and private sector, they could provide an important boost to developing a new consciousness amongst the upcoming generation of South Africans; one that encourages (amongst others) the important civic virtues of reasonableness, tolerance and fair mindedness. ${ }^{38}$

\section{Appendices}

\section{Appendix 1}

Here are some of the responses made by students in response to the question: "What do you hope to achieve by taking this reasoning course?". The sentiments expressed are representative of the vast majority of respondents of all races, male and female students and those ranging from 1st year to 3rd year level.

John: "In taking this reasoning course I hope to broaden perception and understanding of the more complex issues we have been led to believe while maturing (eg: religion, death, freedom) and have not given much structured thought before."

Banikele: "From taking this course I hope to achieve a superior style of thinking that vests one with a feeling of maturity in dealing with either political or social issues."

Kate: "I hope to gain a new view on life. I feel it will enable me to be more accepting of people and situations and I will be able to overcome certain circumstances"

Cheryl: "I believe that it will teach me to think about life, about people and about everyday occurrences that we will take for granted. I will learn to think for myself instead of just accepting what others say."

Jennifer: "I hope to one day realise that there are two sides, sometimes even more, to any and every issue. I hope to question everything my whole life through so that my brain doesn't decay."

Ross: "Greater insight into the way I think and live, the way others think and live and perhaps both in the context of each other."

Jane: "A clearer thinking pattern. Also an ability to view problems and other happenings from a different perspective." 


\section{Stephen de Wijze}

Liza: "Broadening my way of thinking. Seeing things other points of view. I believe that, in many areas, there are no definite answers - due to opinion \& also that there sometimes just isn't an answer. I'd like to explore that."

Evonne: "I hope to be more rational and I would even say wiser for it. I also want to be able to look at things and not just look at it from one side."

Farah: "I hope to gain a better knowledge of how to reason and to always keep an open mind on all matters, even if I disagree with them."

\section{Appendix 2}

\section{Pupil Essays}

I have included two of the better essays and one from the bottom of the class. The standard of all of them is high considering the shortness of the course, the lack of exposure to this type of work and enormous ignorance concerning the arguments for and against vegetarianism. I have reproduced three sets of essays exactly as they were received with their spelling, grammatical and stylistic errors. The three were chosen to illustrate the improvement in the work done. Tom, for example, substitutes the copying of facts from a text on vitamins for an argument even though this activity was explicitly mentioned as a poor way to argue. This was a common error in a number of the essays and I suspect results from the pupils' needs to give facts even if they are not directly related to the argument being made. Luke's work offers a good example of how this module can help someone who is intelligent and resourceful and provide them with a method for effectively arguing their ideas in a logical and clear manner. Andrew's work shows vast improvement from the 1 st to the 2 nd essay. He also indicates a sharp and original mind. Andrew's work tends to be slightly marred by his sometinies poor language skills. Language skills are an essential prerequisite for any critical reasoning course. In doing a critical reasoning course pupils will be improving on their language skills. Those pupils whose language skills are very poor may not benefit from a critical reasoning module. However none of the pupils in this class had this problem.

Title of Essay 1 (Written at the start of the course) - "Why it is right to eat meat." Title of Essay 2 (Written at the end of the course) - Pupils were asked to rewrite the first essay. They could argue either for or against eating meat. This was to be made clear in the title and the introduction of the essay. They were not given a specific length for the essay. It was left to them to decide how long it ought to be.

Student A - Tom

\section{Essay 1}

I think that a person should eat meat. Thinking of a nice hot roast beef sitting on the table makes my mouth just water. Lots of people eat meat so it therefore cant be fatal for a person and except for red meat you can have as much as you like when you like, 
if you like, how you like. There is a lot of protein and iron in meat that helps your body. Although too much meat is a bad thing, too much of anything is a bad thing. It is told that if you eat lots of carrots and drink carrot juice, your hair quite quickly goes orange.

There is also a variety in your diet if you are vegetarian there is only one type of food you can eat while if you are an omnivore there are two dishes minimum that you can eat though. The taste of meat is also in big contrast to that of just vegetables and it is so nice to be able to bite into a nice tender piece of steak.

So the next time you are sitting at Spur, look at a nice succulant piece of spare rib or think of a lekka raw carrot. Make your choice.

\section{Essay 2}

It is good in a nutritional sense to eat meat. The vitamins in the meat including vitamins $A, B, D, E, K$ are essential to the body.

Vitamin $A$ which is needed for vision is not found in plants and vegetables and is found in right proportions in meat. Vitamin $A$ can also be administered to the body for the skin and for mucous membranes. A deficency of vitamin A results in various disorders that most commonly involve the eye. The earliest signs is the lose of night vision which needs a protein found in the eye that maintains it's photosensitivity only in the presence of vitamin A. If insufficient intake of vitamin A is prolonged, the skin may become dry and rough.

Most of the B vitamins have been recognised as coenzymes, and they all appear to be essential in facilitating the metabolic processes of all forms of animal life. Vitamin $B$, a water soluble, nitrogen containing alcohol that is necessary in the diet of all animals to prevent beriberi, a disease characterised by multiple nevritis, general debility and painful rigidity. Pork is one of the richest sources for this Vitamin. Vitamin $B_{1}$ helps the nerves, heart muscles and general metabolism of the human body.

Vitamin $\mathrm{B}_{2}$ is an essential nutrient for the human bodies. Vitamin $\mathrm{B}_{2}$ is known to function as part of metabolic systems concerned with the oxidation of carbohydrates and amino acids and constituents of proteins. Vitamin $B_{2}$ is essential to a number of microscopic animals, including humans. Because vitamin $B_{2}$ is found in animals and not vegetables, complete vegetarianism may lead to deficiencies.

The lack of Vitamin $B_{12}$ makes defective formation of the pupillae of the tongue, giving an appearance of abnormal smoothness. It often causes defective functions of the intestines resulting in indigestion and sometimes constipation. A very serious effect is degeneration of certain motor and sensory tracts of the spinal cord. Initial numbness and tingling of fingers or toes may, without treatment, progress to great instability or virtual paralysis. Deficiency may also result from competition for vita$\min B_{12}$ by the broad tapeworm or by intestinal bacteria growing in cul-de-sacs or above partial obstructions.

Vitamin $\mathrm{C}$ a carbohydrate substance involved in certain metabolic processes of humans. Vitamin $C$ is necessary in the diet of the human in order to prevent scurvy, a disease characterised by hemorrage, especially in the skin and mucous membranes. 
The vitamin is known to be essential in a variety of metabolic functions including synthesis of a protein important in the formulation of healthy skin, tendons, bones, and supporting tissues and in wound healing; maintenance of the structural strength of the blood vessels; metabolism of certain amino acids; and the release of hormones in the adrenal glands. Vitamin $\mathrm{C}$ also plays a large part in the protection of the body against infections.

Vitamin D, either of two fat-soluble alcohols important in calcium metabolism in animals. They are formed by ultraviolet irradiation of sterods present in the skin. Lack of vitamin D causes rickets. A lot of vitamin D is needed to be taken into the body at one time to make a person feel sick or ill.

Vitamin $\mathrm{E}$ has been encouraged in the treatment of numerous diseases, including habitual spontaneous abortion and muscular dystrophy. Also under study is the possibility that vitamin $\mathrm{E}$ may help prolong an active life-span by slowing the rate of oxidative destruction of biological membranes. The characteristics of induced vitamin $\mathrm{E}$ deficiency vary. In females reproduction fails because of absorption of the fetus. In the male, sterility results from degradation of the gaminal tissues.

Lack of vitamin $\mathrm{K}$ in the blood tends to an increase in clotting time of the blood. Blood clotting is delayed or prevented because of the lack of prothrombin, a substance requiring vitamin $\mathrm{K}$ for its synthesis in the liver. In humans deficiency may occur following the administration of certain drugs that inhibit the growth of the vitamins sythesising bacteria.

After having a good look at all the vitamins that meat has in it, it should be clear that eating meat is an essential part of the human consumption.

\section{Student B - Luke}

\section{Essay 1}

Man is a meat eater and so it is pointless and foolish to only eat vegetables and plants.

The reasons for this are many and varied, but probably a very essential one is the fact that creatures throughout time have only begun to advance when consuming their organisms.

Millions of years ago the first forms of life consisted of single celled organisms which did not advance beyond their simple state for a number of millennia. This is because their environment was so hospitable, there were no predators and no dangers because all the other cells photosynthesized for energy. It was only when one cell ingested another that the cycle of natural selection and evolution was created because the surviving cell then went on to create a mass of meat eating progeny, and tactics for avoiding these carnivorous creatures has resulted in the eventual evolution of intelligence.

Therefore we owe our advanced state as human beings to the action of absorbing consuming or eating other animals. Rejecting meat also places the advancement o future races in question: without the natural selection process creatures will stagnat and evolution will come to a grinding halt. 
Second, it is incredibly selfish and close minded to reject food on the basis of belief while thousands all over the world are starving and would do anything for a mere morsel of the food that the vegetarians reject.

Many of the nutriants available in meat are simply not present in plant matter. Extra bulk is also needed to provide nutrition on the same level of meats and thus many cannot afford the added cost.

If man had been consuming animal matter for so many centuries then an abrupt halt in the consumption would create catastrophic effects in the ecological cycle. Many different cultures believe that meat is an important and vital aspect of their society. We cannot infringe on their cultural identity by taking meat off the market. Try and imagine how many jobs would be lost if the meat market collapsed. Think how many people would be placed in incredible financial difficulties if their main source of income went bankrupt, think about not only them but their families and children that rely on them as breadwinners.

Whatever the individual vegetarians reasons for not consuming meat, whether they be moral, philosophical or for health, a couple of crackpot greenies will never make a difference because the majority of people enjoy meat.

All in all I say to you that meat is healthy and enables one to lead a normal well balanced life. Vegetarianism is a pointless and meaningless pursuit and the people who try and spread the word that meat is bad are products of a confused and mixed up society.

\section{Essay 2}

The argument that I am going to present in this essay is one which attempts to conclusively prove that eating meat is an environmentally unsound practise.

In our increasingly environmental conscious world it seems strange that some still argue for meat consumption. The relevance of all other pro-vegetarian arguments sink to insignificance when compared to the immenent danger looming from the Greenhouse effect and the Ozone depletion. I have cut down on the bulk of information and will present the major points.

First, each cow produces an average of two hundred litres of methane a day. This highly toxic and flammable gas is a major contributor to the environmental occurrence called the Greenhouse Effect, in which the Methane in the atmosphere absorbs and stores far more heat than the atmosphere around it. This excess heat from solar radiation remains trapped in the atmosphere and will eventually raise global temperatures by up to ten degrees Celsius. While this temperature change does not seem large and therefore not important, it will have far reaching and catastrophic effects on the way we live. Vast areas of arable land will be lost to the sea as the polar ice melts and the sea rises. There are huge amounts of methane trapped in the polar ice and so the Greenhouse Effect will then increase a thousandfold.

Methane gas is also thought to speed the travel of CFC's into the upper atmosphere. These chemicals destroy the protective ozone layer which shields all life from the sun's Ultra-Violet rays. 


\section{Stephen de Wijze}

Large areas of rainforest are being destroyed to make way for cattle farming. the depletion of these areas will have drastic effects on the Oxygen/air ratios present in our ecosystem.

Areas dominated by cattle ranching are areas experiencing the most erosion and topsoil loss. Overgrazing in many parts of the world, especially Africa, has so depleted the grass and plants whose roots keep the soil in check, that millions of tons of topsoil are lost every year. If we lose this thin life sustaining soil layer we will lose all farming potential in our country. The economic and social effects that this loss will have is incalculable.

The advent of large scale cattle farming in the African continent and elsewhere threatens the very existance of the varied forms of life which used to exist naturally and in harmony with their environment. The competition for food has depleted the herbivores and has resulted in a corresponding depletion in the larger predators, such as the leopard and the lion. These animals can only be found in game parks, little or none of the species remain in the wild.

This is the direct result of cattle farming and can only be remedied if the farming is either stopped altogether or severely cut back.

The argument has been used that the economic burden is too great to halt meat production. This argument looks at term prospects and completely ignores the fact that while the problem can be hidden way for a short while, sooner or later we are going to suffer because of our inaction. Any damage to the environment eventually rebounds back onto mankind in general. This danger outweighs all other pro-meat eating arguments because of the implications for our species.

To produce one pound of meat, a number of pounds of grain is needed. Seeing that not all the cow is used for consumption, food or potential food is being lost. This drastic loss in the foodchain, multiplied by the amount of cattle in the world, creates an imbalance in the ecology which affects our environment at grass roots level.

In this essay I have produced enough evidence to support the conclusion that eating meat is environmentally unsound and in fact in the long run, dangerous to mankind as a whole.

\section{Student C - Andrew}

\section{Essay 1}

I think that eating meat is good and being a vegetarian is not bad, but it is pointless. If you do not have meat in your diet you have to carefully plan your diet so that your body will receive sufficient of the correct nutrients which it would have got from meat in order to live a healthy life.

The most important reason why I eat meat is that it supplies our bodies with protein. This protein gives you energy and so that you can become more active and alert in the classroom as well as on the sports field. In order to get the same amount of protein from vegetables as you do from meat you need to eat a larger quantity than you do for meat. this is time wasting and it also takes up energy. 
Another important factor is that there is nothing more delicious than sitting down to a medium-rare rump steak, served with vegetables and a baked potato. Just thinking about it makes my mouth water and I'm sure even you are beginning to wonder which is better a rump steak or a bowl of salad.

So you are probably thinking that how can you kill an animal and eat it when you have all these wonderful vegetables. But, isn't that the way of nature to kill prey to survive. Well that is just what we are doing except it seems different just because we are more advanced.

So in order to live a much more enjoyable life remembering that you only live once, it is a good idea for all you vegetarians to start eating meat.

\section{Essay 2}

In this essay I will argue that eating meat is ok as long as their is no cruelty inflicted during the raising and slaughtering.

Raising animals in their most natural environment as possible would be an example of raising an animal correctly i.e. A natural habitat for a flock of sheep would be a large open area where they could roam around which also had a good water supply.

Many of the South Africans have large farms and what has just been described in the last paragraph is an exact replica of what the South African farmers give to their flocks of sheep.

Someone may say that breeding animals in captivity is cruel no matter what the circumstances. As you can clearly see that this claim is untrue as wild sheep wont be looked after and they may not have a constant supply of water or grass. When these necessities run out the farmer will move them to the next paddock whereas a wild flock of sheep would die out.

Raising chickens in batteries where they are unable to stand up or even stretch their wings is cruel. Although chickens do not use their wings to fly they do have muscles and will therefore get cramps. On the other hand if chickens kept in a fairly large closed off area where they are able to walk around is a natural habitat for a chicken so this way of breeding chickens is not cruel.

These chickens would also benefit from being in captivity as they would have a constant supply of food and water, they would be able to run around and also have a safe place to lay their eggs where they will be out of harms way. Unlike the wild where they would have to constantly fend for the eggs.

Now that we have discovered that breeding in captivity, as long as it is not cruel is alright and it can and is being done by many farmers.

The next claim is that as long as slaughtering is done as humanely as possible meaning that it is predominately painless and as quick as possible ensuring that animal suffers for the least amount of time it is not cruel and is acceptable.

A counter-claim for this would be that no matter how you slaughter an animal it is cruel as it is taking the life of another animal and there is no way that you can slaughter an animal without being cruel to it.

First it would be much better for the animal to be taken to the abitoir to be slaugh- 


\section{Stephen de Wijze}

tered than to become old and sick in the wild and die a slow death of starvation or to be hunted down by a pride of lions.

The other counter counter claim is that you are able to slaughter an animal without being cruel to it. First you must render the animal unconscious intravenously. Then they should shoot the animal int he head with a captive bolt pistol. (This is a simple pistol which has a large spring which drives the bullet into the animal.) This has been found to be the best method of slaughtering an animal.

This method clearly shows that the animal wont suffer any pain as it is unconscious when the pistol is fired. The method of making the animal unconscious before slaughtering is not cruel. Any other form would be unacceptable as the animal would be able to feel the bullet penetrate before it died.

In this essay I argued that eating meat is ok as long as their is no cruelty inflicted during raising and slaughtering. to support this conclusion I have used the claims that raising an animal in its most natural environment will be uncruel. I have also shown that the counter-claim that breeding animals in captivity is cruel is unacceptable.

To support the other part of the conclusion on slaughtering I used the claim that as long as slaughtering is done humanely as possible meaning that it is predominantly painless and as quickly as possible ensuring that the animal suffers for the least amount of time it is not cruel and should be acceptable. I have also shown that the counter claim that you cannot slaughter an animal and not be cruel is not true.

\section{Notes}

1 "I intend to defend the view that the standard (or familiar) disciplines are the most direct route, if not the only efficacious route, to teaching critical thinking. A consequence of this view is that most of the so-called thinking skills programs, which are so pervasive today, are importantly misguided." (John McPeck in "Teaching Critical Reasoning through the Disciplines: Content versus Process" in Richard A Talaska (ed.) Critical Reasoning in Contemporary Culture, Chapter 2, 31).

2 "The alternative view (critical thinking in the strong sense) rejects the idea that critical thinking can be taught as a battery of atomic technical skills independent of egocentric beliefs and commitments, Instead of 'atomic arguments' (a set of premises and a conclusion) it emphasizes argument networks (worldviews); instead of evaluating atomic arguments it emphasizes a more dialectical and dialogical approach." (in "Teaching Critical Reasoning in the Strong Sense: Getting Behind Worldviews" in Richard Talaska (ed.) Critical Reasoning in Contemporary Culture. chapter 7, 1139-142).

3"Questions and Answers about the Nature and Teaching of Thinking Skills" in Teaching Thinking Skills, Theory and Practice, (eds.) Joan Boykoff Baron and Robert J Sternberg (New York, Freeman:1987) 255.

4 "Critical Reasoning and Informal Logic" in Richard Talaska (ed.) Critical Reasoning in Contemporary Culture.

'Paul, 142.

${ }^{6}$ This is Robert Ennis's definition. See J.A. Blair and R.H. Johnson "Misconceptions of Informal Logic: A Reply to McPeck" in Teaching Philosophy Volume 14, March 1991, Number 1, 11.

${ }^{7}$ Grahamstown is situated about 900 kilometres (550 miles) from Cape Town and 1000 kilome- 
tres (600 miles) from Johannesburg. It is 120 kilometres ( 70 miles) north of Port Elizabeth which is the nearest large city.

${ }^{8}$ The Philosophy Department teaches another first year course - entitled "Logic and the Philosophy of Science" - which has a module on formal logic and a module on informal logic. This course was introduced recently. Its aim is to attract senior students from the science and social science faculties. For various reasons concerning degree curricula of science students, it has not proved very popular - student numbers have not exceeded 10 .

9Students who register for ITP are mostly in the Arts Faculty but there are some from the Commerce and Science Faculties reading ITP as a credit towards their degrees. This course can be taken by 2 nd and 3 rd year students who want a first year credit towards their BA, BComm or BSc degree.

${ }^{10}$ This racial composition is expected to change rapidly over the next few years. Rhodes University is an English medium institution, previously classified as a White university, which due to apartheid laws, consisted of mostly White students and a few Coloured, Indian and Black students who were able to obtain permits to study at Rhodes from the Minister of Education.

"Private schools in South Africa refer to schools which are not funded by the South African government. Most private schools are funded by religious communities for example, the Anglican, Catholic and Jewish communities. Kingswood College is a Methodist private school although one does not need to be a Methodist to attend. These schools have a greater degree of freedom to choose a curriculum and write external examinations (such as the English $A$ and $O$ levels) which differs from those prescribed and administered by the various provincial governments. This system of education will probably undergo significant changes after the new government is elected on April 27th 1994.

${ }^{12}$ An extensive bibliography on the effects of apartheid on education can be found in Kalloway, Peter (ed) Apartheid and Education: The Education of Black South Africans, (Raven Press, Johannesburg: 1988). A book that requires special mention is Ken Hartshome's Crisis and Challenge: Black education 1910-1990 (Oxford University Press, 1992). I offer no explicit critique of $\mathrm{CNE}$ in this paper as my interest is to extract some of the consequences of this educational policy and the problems and possible advantages it provides for those wanting to teach a critical reasoning course.

${ }^{13}$ On the brink of a new political dispensation huge inequities in education spending and classroom conditions still exist. In 1992 the government spent 23 billion rands $(6.39$ billion US\$) or $21 \%$ of their budget on education. This spending was allocated as follows: R1248 (347 US\$) per Black student, R2701 (750 US\$) per Coloured student and R4448 (1236 US\$) per White student. The teacher:pupil ratio in the Western Cape was White 1:17, Coloured 1:23, Indian 1:20 and Black 1:50. (Source: Special Section of The Argus Friday 18 March 1994 - "A Voter's Guide to the Election in the Western Cape").

${ }^{14}$ Viljoen, TA and Pienaar, JJ Fundamental Pedagogics (Durban and Pretoria: 1971) 95.

${ }^{15}$ See Hartshome's Crisis and Challenge, especially chapters 2,3 and 4, for an excellent account of the conditions in the education system which gave rise to the failure to produce critical thinkers.

${ }^{16}$ See Postman and Weingartner Teaching as a Subversive Activity, (Penguin Books, Harmondsworth: 1981), chapter 1.

${ }^{17}$ The information in this paragraph and the quote from Bobby Godsell is taken from a Human Sciences Research Council (HSRC) publication on a symposium and workshop concerning the employability of South African BA graduates. This publication takes the entire issue of Afrika 2001 Vol2 (1) 1993.

${ }^{18}$ Even if the goal of fostering critical thinkers were universally accepted as an educational goal, 


\section{Stephen de Wijze}

it would still need to be justified. This is especially true of a educational goal that has as its aim the teaching of reason and rationality. To ignore claims against it would be to become dogmatic, ideological and clearly contrary to the spirit of what it is to be a critical thinker. ${ }^{19}$ See Harvey Siegel's article "Education and the Fostering of Rationality" in Talaska, 100-101. ${ }^{20}$ Student enrolment in philosophy courses at Rhodes University from 1985 - 1993.

\begin{tabular}{|l|c|c|c|c|c|c|c|c|c|}
\hline & $\mathbf{8}$ & $\mathbf{8 0}$ & $\mathbf{8 7}$ & $\mathbf{8 0}$ & $\mathbf{9}$ & $\mathbf{9 0}$ & $\mathbf{9}$ & $\mathbf{9 2}$ & $\mathbf{9}$ \\
\hline $\begin{array}{l}\text { Introduction to } \\
\text { Philoosophy }\end{array}$ & 34 & 45 & 56 & 99 & 90 & 89 & 103 & 84 & 106 \\
\hline Philosophy 2 & 27 & 26 & 38 & 33 & 18 & 42 & 61 & 67 & 51 \\
\hline Philosophy 3 & 6 & 8 & 10 & 14 & 12 & 6 & 21 & 34 & 43 \\
\hline
\end{tabular}

${ }^{21}$ From April 27, 1994 South Africa will have an interim constitution which will serve the country while negotiations take place for the development of a final constitution - hopefully to be implemented by 1996 .

${ }^{22} \mathrm{As}$ I write the breakdown in the negotiations concerning certain constitutional issues which are of concern to the Inkatha Freedom Party (IFP) has plunged the province of Natal and part of the Transvaal into a low intensity civil war.

${ }^{23}$ Educational authorities do not want to allocate more time and financial resources to critical reasoning courses even though they are enthusiastic about the benefits such courses will bring to their students and pupils. Part of the reason is that the curriculum is already crowded and partly due to the present severe tightening of funds in all educational institutions in South Africa.

${ }^{24}$ See Fisher, Alec The Logic of Real Arguments, (Cambridge University Press, Cambridge:1990), $17 / 18$.

${ }^{25}$ A Practical Study of Arguments, (Wadsworth Publishing Company, Belmont California:1992), 173.

${ }^{26}$ In McDonald, Daniel The Language of Argument, (Fourth Edition) (Harper \& Row, New York: 1983), 17-24.

${ }^{27}$ Siegel, 98.

${ }^{2836}$ Teaching Critical Reasoning through the Disciplines: Content versus Process", 31.

${ }^{29} \mathrm{Ibid}, 33$.

${ }^{30}$ Ibid., 31.

${ }^{31}$ See Ennis' article "Conflicting Views on Teaching Critical Reasoning" in Talaska, 7-9.

${ }^{32}$ This characterisation of McPeck's argument I have taken from M Vermaak's paper "Transferable Thinking Skills?" published in the Proceedings of the 7th Conference of the South African Association for Academic Development (SAAAD), 3-5 December 1992.

${ }^{33}$ Vermaak, 140.

${ }^{34}$ In an assessment of the module given to pupils at Kingswood College evidence that the module was considered useful was obtained from the pupils and class teacher herself. I also 
wanted to establish whether the writing of argumentative essays was considered to be an appropriate skill for pupils given the demands of the Matric syllabus and the skills required to excel in a Matric English examination. I was concerned that the type of essays required for success in an English Matric examination were quite different from that which is expected from a critical argumentative essay. The former stressing creativity, lateral thinking and the expressing of personal feelings while the latter strongly emphasised essay structure, logical reasoning and simple, clear, unambiguous language. Consequently, I asked the class teacher to read the essays and indicate whether she found these essays to be either:

a) An improvement on their normal work;

b) Of the same standard;

c) A retrogression in the standard of work normally received.

Her comments were very encouraging. Of the 17 pupils, 15 fell into categories a and $b$ above either maintaining their normal standard or substantially improving their standard of work. Penny describes some of the 2 nd essays in glowing terms:

"Essay 2 is much better than essay 1. I am impressed that Julia has applied herself to researching as thoroughly as she obviously has for essay $2 "$

"Essay 2 is probably the most coherent piece of work produced to date."

"Essay 2 is certainly in line with what I expect Luke to produce - perhaps better than normal as it has required him to take a more structured approach rather than simply rely on his language skills."

"Essay 2 is surprisingly coherent - hopefully this indicates a general improvement."

"Essay 2 much better. Probably the best thing Andrew has produced to date."

Pupils themselves also perceived the module to be useful. In a module evaluation the pupils were asked if they found this module useful for their other school subjects, for a general understanding of the world and for their everyday activities. The replies of those that responded to this question were:

"Yes, it helps how to write this type of essay, especially for subjects such as history and biology."

"Yes, because now I know how to argue properly."

"Yes. It helped with history."

"Yes, English and History argumentative skills were improved and further refined. I found that my ability to promote ideas were strengthened."

"Yes it helps you to look at the pros and cons of different points."

"Yes, I now have reference as to how to argue properly, and compromise, which I think is essential for the future."

"No, not at the moment. It may be useful later though."

When asked if they would recommend that a module of this kind be taught to other pupils at Kingswood, all but one of the respondents agreed that it would be a good idea.

Concerning students, the increase in numbers opting to do philosophy at Rhodes can in part be explained by their belief that philosophy will teach them critical reasoning skills. This belief derives partly from talking to previous year students who claimed such courses have indeed helped them and from the popular general idea that philosophy teaches people how to think. (Students make these points in a questionnaire they complete when registering for ITP course at the beginning of the academic year.)

${ }^{35}$ Michael Scriven in a lecture at the 2 nd British Conference on Critical Thing and Education (6-8 April at University of East Anglia) in a paper entitled "Defining and Assessing Critical Thinking" points out that just learning the standard 60 terms of logical enquiry (words such 
82 Stephen de Wijze

as validity, presupposition, assumption etc.) is to learn knowledge which is important for developing the ability to become a critical thinker.

${ }^{36}$ Paul, 143-144.

${ }^{37} \mathrm{Paul}, 151$.

${ }^{38}$ I am indebted to Julia Segar for useful comments on an earlier draft. I am especially indebted to Marius Vermaak for useful comments on this paper and who has taught a number of critical reasoning courses with me over the last few years.

STEPHEN DE WIJZE DEPARTMENT OF GOVERNMENT THE UNIVERSITY OF MANCHESTER

OXFORD ROAD MANCHESTER

$M 139 P L$

UNITED KINGDOM msrgssw@fsI.ec.man.ac.uk 